\title{
A NOVA MULHER EM UMA NOVA COMUNIDADE: UM RECORTE ENTRE AS COMUNIDADES TRADICIONAIS E AS SOCIEDADES ATUAIS EM MATÉRIA DE GÊNERO ${ }^{1}$
}

THE NEW WOMAN IN A NEW SOCIETY: A VIEW OF TRADITIONAL AND MODERN SOCIETIES IN RELATION TO GENDER

LA NUEVA MUJER EN UNA NUEVA COMUNIDAD: UN ENFOQUE DE LAS COMUNIDADES TRADICIONALES Y LAS SOCIEDADES ACTUALES EN MATERIA DE GÉNERO

\section{Eliane Fontana ${ }^{2}$}

\section{Marli Marlene Moraes da Costa ${ }^{3}$}

1 Artigo final apresentado à disciplina Políticas Públicas de Gênero, no Programa de Pós-Graduação em Direito - Doutorado da Universidade de Santa Cruz do Sul - UNISC, ministrada pela professora Pós-Doutora Marli Marlene Moraes da Costa.

2 Doutoranda do PPG-Doutorado UNISC. Mestre em Direito pelo PPG-UNISC. Professora da Faculdade de Direito no Centro Universitário UNIVATES em Lajeado - RS. Membro do Grupo de Pesquisa Comunitarismo e Políticas Públicas, vinculado ao CNPq. Advogada. Contato: eliane.fontana859@gmail.com

3 Pós-Doutora em Direito pela Universidade de Burgos/Espanha, com Bolsa CAPES. Doutora em Direito pela Universidade Federal de Santa Catarina - UFSC, professora e coordenadora do Programa de Pós-Graduação em Direito - Mestrado e Doutorado na Universidade de Santa Cruz do Sul - UNISC, Professora da Graduação em Direito na FEMA - Fundação Educacional Machado de Assis de Santa Rosa, Coordenadora do Grupo de Estudos "Direito, Cidadania e Políticas Públicas" da UNISC. Psicóloga com Especialização em Terapia Familiar - CRP n. 07/08955, autora de livros e artigos em revistas especializadas. Contato: marlim@unisc.br. 
Resumo: Esta pesquisa busca demonstrar que a capacidade para uma nova comunidade e uma nova mulher passa pela rejeição de tradições que replicam o velho paradigma da estratificação da mulher. As sociedades atuais seguem perpetuando valores culturais que referendam a desigualdade de gênero tal como nas comunidades tradicionais, e que apesar das muitas conquistas - social, política, educacional e jurídica -, ainda não houve sua erradicação. Acredita-se que somente por meio de uma mudança nos valores, ou seja, na cultura de valores, é que haverá o rompimento da visão binária que estratifica as relações sociais. A cultura secular desemboca em um sistema de sujeições, de dominação e de poder, replica naturalmente as desigualdades e impede que se rompam os ciclos de desigualdade e que se acabe com os números assombrosos de violência e discriminação. Existe uma nova mentalidade para a construção de uma nova sociedade revigorada? Parece que ainda não, mas existe, sim, uma nova mulher que precisa se ver e praticar hábitos que ampliem a visão de seu papel e do papel da sociedade. Trat5a-se de uma pesquisa exploratória, cujo método de abordagem é o hipotético-dedutivo.

Palavras-Chave: Comunidade. Gênero. História da mulher.

Abstract: This research seeks to demonstrate that the ability to create a modern society and a new woman involves a process of rejecting traditions that replicate the old paradigm of stratification of women. Modern societies continue to perpetuate cultural values that endorse gender inequality, as in the traditional societies, and despite the many achievements - social, political, educational and juridical - it has still not been eradicated. It is believed that only through a change in the values, i.e. in the culture of values, will it be possible to break with the binary vision that stratifies social relationships. Secular culture leads to a system of subjections, domination, and power, naturally replicates inequalities, and prevent the cycles of inequality, which result in staggering figures of violence and discrimination, from being broken. Is there a new mindset for the construction of a new invigorated society? It appears that there is not, yet, but there is a new woman who needs 
to see herself and practice habits that expand the vision of her role and that of society. This is an exploratory study that uses the hypothetical-deductive method.

Keywords: Gender. History of women. Society.

Resumen: Esta investigación pretende demostrar que la capacidad para una nueva comunidad y una nueva mujer requiere el rechazo de tradiciones que repiten el viejo paradigma de la estratificación de la mujer. Las sociedades actuales siguen perpetuando valores culturales que confirman la desigualdad de género tal como era en las comunidades tradicionales, y que a pesar de las numerosas conquistas - social, política, educacional y jurídica -, todavía no se vio su erradicación. Se afirma que solo por medio de un cambio en los valores, es decir, en la cultura de valores, habrá una ruptura de la visión binaria que estratifica las relaciones sociales. La cultura secular desemboca en un sistema de sumisiones, de dominación y de poder, reproduce naturalmente las desigualdades e impide que se rompan los ciclos de desigualdad y que se acabe con los números asombrosos de violencia y discriminación. ¿Existe una nueva mentalidad para la construcción de una nueva sociedad revitalizada? Parece que todavía no, pero existe, sí, una nueva mujer que precisa verse y practicar hábitos que amplíen la visión de su papel y del papel de la sociedad. Se trata de un estudio exploratorio, cuyo método de abordaje es el hipotético deductivo.

Palabras clave: Comunidad. Género. Historia de la mujer.

INTRODUÇÃO

ste artigo científico buscará demonstrar que, as sociedades atuais, muito embora tenham evoluído em diversas áreas desde as chamadas comunidades tradicionais, - notadamente no campo social, político, educacional e jurídico-, seguem perpetuando valores culturais que referendam a desigualdade de gênero. O trabalho objetivará referendar a importância de 
todas as lutas (sobretudo social e jurídica), mas acredita que somente com uma mudança no campo dos valores, ou seja, na cultura de valores, é que haverá o rompimento da visão binária que estratifica as relações sociais.

Em matéria de tempo e espaço, este breve estudo terá saltos históricos num contraponto ao panorama atual brasileiro, bem como se refere estritamente ao Ocidente. Não se trabalhará com um histórico minucioso de legislações protetivas em matéria de gênero, pois o objetivo principal não é demonstrar a visão normativa, mas chamar a atenção à manutenção dos valores que internalizam desigualdades na sociedade civil.

Para tal, no primeiro ponto se verão alguns desenhos teóricos do que era a formação de uma comunidade tradicional, quais seus principais estudiosos e as noções e a importância do estudo de comunidade na seara da ciência social para depois localizar a história da mulher nesse contexto.

Em seguida - sem ter a pretensão de esgotamento - versará acerca da história da mulher na construção social e teórica do mundo. Discorrer-se-á sobre as evoluções e sobre as velações do papel da mulher na história das comunidades, e do combate às desigualdades, especialmente, à discriminação, que requer atitudes não só punitivas, mas também atos que construam uma nova cultura política brasileira.

Por fim, no último ponto, reconhecer-se-á que a nova mulher é, na realidade, uma "super" mulher, ambientada numa sociedade em que os avanços legais foram muitos, mas que segue os parâmetros das comunidades tradicionais. Por outro lado, visando ter a ideia prospectiva, a transformação deverá ser axiológica, cultural e interna. Na medida em que os ranços tradicionais se reproduzirem na criação dos filhos, todo o esforço teórico e intelectual (e também normativo) não terá alcançado o objetivo de empoderar a mulher na exata medida da dignidade e da importância de sua existência.

A pesquisa é exploratória, cujo método de abordagem é o hipotético-dedutivo. O artigo é norteado pela pesquisa bibliográfica, de doutrinas e estudos de dados, notadamente àqueles embasados pela disciplina de doutoramento, que foi base para o estudo. 


\section{COMUNIDADES TRADICIONAIS E SUAS CONTRADIÇÕES}

Para demonstrar a ideia de comunidade tradicional, a primeira parte desta pesquisa se dará percorrendo alguns pontos para desenhar o que era a formação e a noção de comunidade para depois, num segundo momento, localizar a história da mulher nesse contexto.

A importância atribuída à cultura política e à sociedade civil está presente em quase todos os clássicos da democracia, como Tocqueville, Rousseau, Aristóteles, Platão e nas mais recentes reflexões sobre a importância de trazer de volta o cidadão para a esfera política (Habermas, Pateman, Mouffe, Giddens, Touraine).

Em um primeiro estágio, a sociedade política volta-se às necessidades diárias e agrupa-se ao modo mais simples, que é a família. Já as famílias, em conjunto, formam a comunidade visando à utilidade comum. Porém o Estado se antepõe à família, pois o todo deve ser posto antes da parte e, desse modo, a própria natureza faz com que os homens se associem. Portanto "o homem é um animal político por natureza, que deve viver em sociedade, e que aquele que, por instinto e não por inibição de qualquer circunstância, deixa de participar de uma cidade, é um ser vil ou superior ao homem"4 . Assim, Aristóteles explica a impossibilidade de ascensão social e a justifica dizendo que tal é obra da natureza, ou seja, aprisiona o homem em sociedade.

Para Aristóteles a comunidade existe por questão da necessidade de ser feliz, por isso é tão importante e anterior à própria família e identifica os atores dentro da sociedade, a constituição e a divisão de poder. Não refere ao porquê de se participar politicamente, mas apenas que em participando pode-se garantir o ter, ou seja, o patrimônio, e este vincula a sociedade à felicidade.

Ferdinand Tõnnies, em sua emblemática obra Comunidade e Sociedade, construída para trabalhar as noções de ambas, ganha sugestiva importância nos dias atuais frente ao modelo de organização social que seria melhor para o homem e suas aspirações. Tal debate é aquele que confronta, de um lado, o modelo liberal, de outro, o modelo socialista ${ }^{5}$. Ferdinand Tõnnies, em 1887,

4 ARISTÓTELES. Política. São Paulo: Martin Claret, 2002. p.14.

5 OLIVEIRA, Luciano. Comunidade e sociedade - notas sobre a atualidade do pensamento de 
tratou a sistematização entre o dualismo sociedade (Gemeinschaft) e comunidade (Gessellschaft) no discurso científico contemporâneo. Sua divisão propôs que por comunidade entende-se uma unidade de vontade humana natural estreita, representada por relações familiares (mãe /filho), marido e mulher, entre irmãos. Ainda refere que há comunidades de sangue, de lugar, pensamento, parentesco, amizade e comunidades espirituais. Há na comunidade uma unidade orgânica que se manifesta no afeto. Por outro lado, a sociedade seria a construção artificial "de una amalgama de seres humanos que em la superficie se asemeja a la gessellschaft o comunidad [...] mientras que en la gemeinschaft permanecen esencialmente separados a pesar de todos los factores tendentes a su unificación" (2006, p. 35). Ou seja, uma sociedade (ou associação) é uma constituição de interesses, uma união contratual, como seriam as relações mercadológicas.

Para Schmidt ${ }^{6}$, comunidade é elemento central da cristandade medieval, mas recusada por grande parte do pensamento iluminista moderno. Para o autor, a comunidade "é redescoberta no pensamento social europeu ao longo do século XIX e assume relevância crescente ao longo do século XX, mantida nos dias atuais". Também Durkhein (1988) trouxe comparações entre sociedades orgânicas e sociedades mecânicas e considerou a "transição da solidariedade mecânica para a solidariedade orgânica um aspecto geral da modernização".7

A comunidade é a finalidade última do ser humano - equivale à própria vida - e, para Buber ${ }^{8}$, a "vida nasce de comunidades e aspira à comunidade. A comunidade é fim e fonte de vida", sendo ele. Para o autor, a afirmação do princípio comunitário na era moderna há de se dar no quadro de uma sociedade de estrutura rica, ou seja, permeada por uma multiplicidade de associações e agrupamentos autônomos e das federações dessas organizações, em linha com o socialismo utópico, que luta pelo máximo de autonomia comunitária possível ${ }^{9}$.

Ferdinand Tõnnies. Cad. Estudos Soc., Recife, v.4 n.J,p.IOS-118,jan./jun., 1988.

6 SCHMIDT, João Pedro. Comunidade e comunitarismo: considerações sobre a inovação da ordem sociopolítica. Ciências Sociais Unisinos, São Leopoldo, Vol. 47, N. 3, p. 300-313, set/dez 2011. p. 301.

7 INGLEHART, Ronald; WELZEL, Christian. Modernização, mudança cultural e democracia: a sequência do desenvolvimento humano. Trad. Hilda Maria Lemos Pantoja. São Paulo: Francis, 2009. p. 172.

8 BUBER, Martin. 2007. O socialismo utópico. 2. ed. São Paulo: Perspectiva. p. 34.

9 SCHMIDT, João Pedro. Comunidade e comunitarismo: considerações sobre a inovação da ordem sociopolítica. Ciências Sociais Unisinos, São Leopoldo, Vol. 47, N. 3, p. 300-313, 
No momento atual, em que a ciência social volta os olhos aos estudos de comunidade, nasce a seguinte indagação: a comunidade tem alguma função importante nos dias atuais? A resposta é sim. Viver em comunidade, além de prazeroso, é saudável e faz as pessoas viverem mais e melhor. Num contexto econômico leva-se em conta o fato de o cidadão adoecer menos e isso reflete nos gastos do Estado em saúde. Já é sabido que o estado de espírito cooperativo, ou seja, a relação em que as pessoas se beneficiam, é algo que naturalmente está no ser humano por ser este um animal social ${ }^{10} \mathrm{e}$, portanto, as trocas se darão por inúmeras formas e é o caminho natural para o fortalecimento do próprio homem. Este é o foco também de uma pesquisa interessante de Cacioppo (2010), quando releva as mazelas da solidão para os seres humanos, nos aspectos físicos e sociais, dando ênfase ao nível de vulnerabilidade social como "dor social" (2010, p. 24). A importância da comunidade se dá, notadamente, para Cacioppo, em prevenir doenças e trazer sensações de acolhimento que afastam o ser humano de patologias físicas e sociais.

O sociólogo polonês Bauman ${ }^{11}$ possui uma obra intitulada Comunidade e já na sua introdução faz perceber que ela difere de uma organização artificial de sociedade. Para Bauman, a ideia de comunidade guarda sentidos cálidos e confortantes, além de dizer que:

[...] é bom "ter uma comunidade," "estar numa comunidade". Se alguém se afasta do caminho certo, frequentemente explicamos sua conduta reprovável dizendo que "anda em má companhia". Se alguém se sente miserável, sofre muito e se vê persistentemente privado de uma vida digna, logo acusamos a sociedade - o modo como está organizada e como funciona. As companhias ou a sociedade podem ser más; mas não a comunidade. Comunidade, sentimos, é sempre uma coisa boa. $^{12}$

set/dez 2011.

10 SENNETT, Richard. A cultura do novo capitalismo. Tradução Clóvis Marques. Rio de Janeiro: Record, 2006. p. 15.

11 Também são de Bauman as definições de sociedades éticas e estéticas, mas, a título de opção por inúmeros caminhos teóricos, deixou-se esta para outro momento trabalhar.

12 BAUMAN, Zygmunt. Comunidade: a busca por segurança no mundo atual. Trad. Plínio Dentzien. Rio de Janeiro: Jorge Zahar, 2003. p. 7. 
Embora o trecho reflita a abordagem aconchegante com que Bauman expõe a vida em comunidade, adentrando a obra o autor se preocupa em refletir sobre duas tendências que acompanharam o capitalismo moderno: por um lado, o esforço de substituir o 'entendimento natural' da comunidade de outrora, o ritmo, "regulado pela natureza, da lavoura, e a rotina, regulada pela tradição, da vida do artesão, por outra rotina artificialmente projetada e coercitivamente imposta e monitorada"13. e, de outro lado, a tendência de criar do nada um sentido de comunidade dentro do quadro de uma nova estrutura de poder, ou seja, a busca pela naturalização dos padrões de conduta ${ }^{14}$ impostos pelo processo de racionalização, "abstratamente projetados e ostensivamente artificiais"15.

Etzioni importa-se em conceituar comunidade e nela contempla afeto e valores como a comunhão que a une:

A comunidade é definida por duas características: primeiro, um efeito da onda de relações carregadas entre um grupo de indivíduos, relacionamentos que muitas vezes se cruzam e se reforçam um ao outro (em vez de meras relações de um para outro, ou de uma cadeia de relações individuais); o segundo, um compromisso quota-parte de um conjunto de valores compartilhados, normas e significados, e uma história e identidade compartilhada, isto é, em uma palavra, com uma cultura. ${ }^{16}$

Na medida em que esses são os elementos nodais, anuncia-se a necessidade de serem mais locais, embora isso não seja necessariamente sinônimo de "pequenas". A comunidade é o local onde o cidadão se reconhece e compartilha o que igualmente acredita em termos de laços de afeto e valores. Assim, para ter um recorte maior de comunidade, somente naquilo que Etzioni chama de "comunidade de comunidades" é um desafio particularmente difícil para os comunitários que tratam de fomentar as comunidades, porque quanto mais fortes são as comunidades, menos possíveis de atuarem como membros de um

13 BAUMAN, Zygmunt. Comunidade: a busca por segurança no mundo atual. Trad. Plínio Dentzien. Rio de Janeiro: Jorge Zahar, 2003. p. 36.

14 LEMOS, Carolina Teles. A (re)construção do conceito de comunidade como um desafio à sociologia da religião. Revista Estudos de Religião, v. 23, n. 36, 201-216, jan./jun. 2009.

15 BAUMAN, Zygmunt. Comunidade: a busca por segurança no mundo atual. Trad. Plínio Dentzien. Rio de Janeiro: Jorge Zahar, 2003. p. 39.

16 ETZIONI, Amitai. La tercera via hacia una buena sociedad: propuestas desde El comunitarismo. Sagasta: Trotta,S. A, 2000. p. 157. 
todo mais extenso ${ }^{17}$. As pessoas se aproximam em valores com regiões próximas, bairros, grupos de trabalhos, "tribos urbanas", cidades, famílias. Desse modo, em nível agigantado - tal como país -, fica mais difícil falar em afetos, mas, talvez, em afinidade. Por sua vez, o que os comunitaristas chamam de boa sociedade, tem em seu âmago um núcleo de valores compartidos e isso também reforça a habilidade de uma sociedade formular políticas públicas específicas, no caso em voga, em questões de gênero.

O fato é que nem Aristóteles (para quem a mulher nem cidadã era), nem Tõnnies, nem Weber e nem mesmo Bauman, especificadamente referendaram a medida e o papel da mulher nas comunidades tradicionais de maneira que o que se pode dizer é que, na mais simples descrição, no mínimo, comunidade geralmente indica um grupo de pessoas dentro de uma área geográfica limitada, que interage dentro de instituições comuns e que possui um senso comum de interdependência e integração ${ }^{18}$. Todavia as comunidades tradicionais, embora comunguem de boas vibrações, nunca deixaram de acobertar a opressão à mulher e é nesse ponto que talvez os autores (re)tocam o tema comunidade nos dias de hoje. Para Negreiros, os papéis masculino e feminino configurariam tipificações do que seria pertinente ao homem e à mulher num dado contexto ${ }^{19}$.

Ainda Negreiros destaca que existem dois modelos a serem analisados na perspectiva de gênero ${ }^{20}$; um tradicional e outro igualitário, ou seja, o novo e o antigo convivem na subjetividade, sem que o primeiro tenha substituído o segundo, como aparentemente se pode supor ${ }^{21}$. Os modelos se divorciam no seguinte sentido:

17 ETZIONI, Amitai. La nueva regla del oro: comunidad y moralidad em uma sociedad democrática. Barcelona: Paidós, 1999. p. 225.

18 BOTTOMORE, T. Dicionário do pensamento social do século XX. Rio de Janeiro: Zahar, 1996. p. 115.

19 NEGREIROS, Teresa Creusa de Góes Monteiro. Masculino e feminino na família contemporânea. Revista Estudos e Pesquisas em Psicologia, UERJ, RJ, ano 4 n. 1, 10 semestre 2004.

20 O termo gênero surgiu no bojo das reivindicações do movimento feminista como uma tentativa de explicar o caráter social dos papéis sexuais destinados a homens e mulheres. Tal conceito difundiu-se no Brasil a partir da década de 1990, com o famoso texto da historiadora Joan Scott, Gênero: uma categoria útil de análise histórica. Desde então, vem ganhando espaço nas discussões empreendidas pelas ciências humanas e sociais e na elaboração de políticas públicas que visam à equidade entre homens e mulheres (SILVEIRA, 2014)

21 NEGREIROS, Teresa Creusa de Góes Monteiro. Masculino e feminino na família contemporânea.

Revista Estudos e Pesquisas em Psicologia, UERJ, RJ, ano 4 n. 1, 10 semestre 2004. 
No "modelo antigo" os dois sexos são concebidos como "naturalmente" diferentes, tanto bio-psíquica como socialmente. As identidades masculinas e femininas configuram-se demarcadas com precisão - o que cabe a um exclui o outro, quer em comportamentos, atitudes, sentimentos, inclinações ou interesses. [...] A masculina é fundada na relação com o trabalho e na virilidade - manutenção econômica da família e atitude protetora para com os seus membros. A feminina está calcada na preservação da sexualidade e no exercício da maternidade - virgindade pré-nupcial, fidelidade conjugal e dedicação ao lar e filhos. [...] O "modelo novo" é marcado pelo fenômeno do individualismo, peculiar dos grandes centros urbanos brasileiros e absorvido principalmente pelos segmentos médios, onde o processo de modernização se expandiu intensa e rapidamente ${ }^{22}$. (Grifo nosso).

O que se denota do texto é que a contemporaneidade trouxe novos preceitos de um ideal de comunidade, e tanto se pode chamar de comunidade, ainda, como de sociedade, para outros, mas num compasso que não superou velhos paradigmas. O novo não substituiu o velho, mas convive com o que sempre existiu. Assim, a história da mulher foi ganhando cor e notabilidade a partir do século XIX; e espaço, ao longo do século XX, porém as gerações que vieram carregaram ranços discriminatórios que ecoam hoje como entraves para a completa igualdade de seu papel nos dias atuais. A história escrita solidificou mitos que replicaram um ideário de mulher e homem com papéis frontalmente diferente, enquanto recortes fundamentais, como dizer que "em momento algum na pré-história as mulheres, com ou sem filhos, dependeram da caça dos machos para a sua alimentação" 23 , ficaram de fora.

Para Pateman ${ }^{24}$, grave é considerar que a liberdade civil, na história, é atributo masculino e depende do direito patriarcal ${ }^{25}$. Para ela, a sociedade não está fundada 22 NEGREIROS, Teresa Creusa de Góes Monteiro. Masculino e feminino na família contemporânea. Revista Estudos e Pesquisas em Psicologia, UERJ, RJ, ano 4 n. 1, $1^{\circ}$ semestre 2004. p. 38.

23 MILES, Rosalind. A história do mundo pelas mulheres. Trad. Bárbara Heliodora. Rio de Janeiro: LTC, 1989. p. 22.

24 PATEMAN, Carole. O contrato sexual. Rio de Janeiro: Paz e Terra. 1993. p. 17.

25 Sobre os termos gênero e patriarcado, Saffioti (2004) assinala que o termo gênero não pressupõe necessariamente uma hierarquia entre homens e mulheres. Diz, assim, que algumas feministas presumem tal hierarquia independente do período histórico analisado. Por essa razão, há dificuldade em se utilizar corretamente os conceitos de gênero e de patriarcado. Ao defender o uso simultâneo desses dois conceitos, a autora argumenta que o termo gênero é mais amplo que a noção de patriarcado, pois o primeiro deixa aberta a possibilidade do vetor dominação-exploração em suas relações e o segundo marca a dominação do homem sobre a mulher. (SILVEIRA, 2014 apud SAFFIOTI, 2004). 
no poder dos pais, mas as mulheres estão subordinadas aos homens "enquanto homens" e sublinha ainda que "o contrato ${ }^{26}$ original é feito depois da derrota política do pai e cria o patriarcado fraternal moderno."

Para Pateman:

[...] Argumentar que se combate melhor o patriarcado através de esforço de transformação da diferença sexual em algo politicamente irrelevante é aceitar a visão de que o domínio civil (público) e o indivíduo não estão contaminados pela subordinação patriarcal. O patriarcado é entendido, então, como um problema privado e familiar que pode ser resolvido se as leis e políticas públicas tratarem as mulheres como sendo exatamente iguais aos homens. Entretanto, o patriarcado moderno não é relativo, primordialmente, à sujeição familiar da mulher. As mulheres têm relações sexuais com homens e são esposas antes de se tornarem mães de família. A história do contrato sexual é sobre relações (hetero)sexuais e sobre mulheres personificadas como seres sexuais ${ }^{27}$. (Grifo nosso).

E a história contratual descrita se deu porque, culturalmente, os sistemas patriarcais enfatizaram a fragilidade das mulheres e sua inferioridade ao longo de uma história contada apenas por homens. Na construção da civilização e no âmbito patriarcal de excelência havia uma insistência nos deveres domésticos e que, algumas vezes, restringiam os direitos das mulheres aparecerem em público. $\mathrm{O}$ alcance do patriarcalismo foi poderoso e extenso ${ }^{28}$. Além do mais, a desigualdade das mulheres "tendeu a aumentar com o passar do tempo, à medida que as civilizações agrícolas se tornavam mais bem-sucedidas" (2013, p. 33).

E pode-se dizer que há um novo contrato após as transformações políticosociais do Ocidente ao longo da história? Há quem sustente que sim, refletida na expansão do Estado de Bem-Estar, na modernização pós-industrial e no natural alvorecer da democracia das massas e no desenvolvimento humano. Ou seja, há, sim, valores emancipadores da mulher no processo histórico, "entretanto, apesar da globalização- o mundo não está se tornando homogêneo e a marca

26 Para Pateman, "o contrato sexual é o meio pelo qual os homens transformam seu direito natural sobre as mulheres na segurança do direito patriarcal civil." ( 1993, p. 21)

27 PATEMAN, Carole. O contrato sexual. Rio de Janeiro: Paz e Terra. 1993. p. 35.

28 STEARNS, Peter N. História das relações de gênero. Tradução Mirna Pinsky. 2. ed. São Paulo: Contexto, 2013. p. 16. 
das tradições culturais não está desaparecendo"29. O sistema de valores continua a replicar velhos estigmas e a passar às gerações as restrições humanas. A cultura é transmitida por meio de gerações e o que se denota é que a construção de leis (produção normativa), bem como uma significativa quantidade de políticas públicas que desenvolvam a igualdade de gêneros, não é suficiente para a transformação para ressignificação da mulher no contexto de mundo Ocidental. Do ponto de vista dessas perspectivas alternativas, a cultura é vista como dinâmica e não estática e que evolui constantemente sob a influência de fatores externos e internos. Sua base, no entanto, constitui-se de fatores duradouros que a tornam diferente de outras culturas. Tal síntese materializa-se em crenças, predisposições, motivações e normas de fazer as coisas de um povo. No entanto, junto com valores positivos, são construídos valores que influenciam a forma como as pessoas fazem e veem as coisas em um determinado contexto ${ }^{30}$.

O processo de transformação cultural não é linear e, para Inglehart e Welzel, a direção predominante da mudança alterou-se repetidas vezes no curso da história. E nesse processo a industrialização teve certo peso, bem como (e, por consequência) a ascensão das sociedades pós-industriais gerou outro importante processo de mudança, que se move num sentido dos valores de autoexpressão, por meio dos quais "as pessoas valorizam cada vez mais a escolha humana, a autonomia e a criatividade" ${ }^{\prime 31}$. E importante observação os autores apontam: "as pessoas de sociedades mais pobres, onde o setor agrário supera o setor industrial, tendem manter valores tradicionais, enquanto as pessoas de sociedades mais ricas, onde o setor industrial supera o agrário, tendem a manter valores seculares-racionais". ${ }^{32}$

29 INGLEHART, Ronald; WELZEL, Christian. Modernização, mudança cultural e democracia: a sequência do desenvolvimento humano. Trad. Hilda Maria Lemos Pantoja. São Paulo: Francis, 2009. p. 20.

30 BAQUERO, Marcello. Construindo uma outra sociedade: o capital social na estruturação de uma cultura política participativa no Brasil. Revista de Sociologia e Política, Curitiba, n. 21, p. 83-108, nov. 2003. Disponível em:<http://www.scielo.br >. Acesso em: 09 de novembro de 2014. p. 90.

31 INGLEHART, Ronald; WELZEL, Christian. Modernização, mudança cultural e democracia: a sequência do desenvolvimento humano. Trad. Hilda Maria Lemos Pantoja. São Paulo: Francis, 2009. p. 41.

32 INGLEHART, Ronald; WELZEL, Christian. Modernização, mudança cultural e democracia: a sequência do desenvolvimento humano. Trad. Hilda Maria Lemos Pantoja. São Paulo: Francis, 2009. p. 103. 
Assim, é na comunidade que se criam e recriam os valores e a cultura política de uma sociedade. A mudança não se dá pela via legal, mas deve ser transformada por meio de valores. Para o ícone do comunismo responsivo ${ }^{33}$, o israelense naturalizado americano, Amitai Etzioni, a comunidade proporciona a formação de laços de afeto que transformam grupos em entidades sociais parecidas com famílias grandes; concomitantemente transmitem uma cultura moral compartida ${ }^{34}$. Para ele as sociedades democráticas costumam ser menos opressoras porque as pessoas podem escolher os grupos a que desejam pertencer, porém isso não é uma verdade inafastável, ${ }^{35}$ já que o processo de modernização trouxe consigo a ainda constatável (e triste) mantença de dados alarmantes envolvendo violência física, psíquica, moral e sexual em mulheres no mundo, bem como femicídios "velados" num universo que ainda não contabiliza com exatidão o tamanho da distância que ainda há entre o tratamento (des)igualitário entre os gêneros na atualidade.

Para o comunitarismo, a formação da comunidade exige laços, valores morais em comum e afeto. Para Etzioni, a transmissão de valores morais é a finalidade principal da comunidade. Os grupos baseados somente no interesse são categorizados como "grupos de interesse" e não comunidade, pois não consideram as pessoas fins em si mesmas. Embora os estudos de Etzioni não estejam sistematizados às questões de gênero, é possível dizer que hoje comunidade não mais é tida no seu sentido tradicional, de lugar pequeno e fechada, isolada do global; independentemente do tamanho e do local. A ideia de

33 Em novembro de 1991 foi divulgada a plataforma programática do movimento comunitarista responsivo - The Responsive Communitarian Platform: Rights and Responsibilities documento que ainda constitui-se como referencial dos responsivistas norte-americanos. A versão inicial foi formulada por Etzioni e discutida por um grupo de intelectuais vinculados a distintas linhas de pensamento, sendo o documento assinado por 104 signatários. Entre as linhas básicas da Plataforma encontram-se as seguintes: a importância da comunidade na existência humana; o indispensável equilíbrio entre a liberdade e responsabilidade, entre o bem comum e a autonomia individual; o papel da voz moral frente ao Estado e ao mercado, exercido pela persuasão e pela educação; o fortalecimento da democracia através do incremento da representação, da participação e da responsividade da política em relação aos cidadãos; a centralidade dos valores e deveres cívicos, da ética na política; a afirmação da democracia forte A escolha do adjetivo responsivo (responsive) deu-se no contexto das preocupações em se diferenciar de outras formas de comunitarismo, particularmente do modelo comunista e do modelo asiático. (SCHMIDT, texto inédito, p. 3-4)

34 ETZIONI, Amitai. La tercera via hacia una buena sociedad: propuestas desde El comunitarismo. Sagasta: Trotta,S. A, 2000. p. 24.

35 ETZIONI, Amitai. La tercera via hacia una buena sociedad: propuestas desde El comunitarismo. Sagasta: Trotta,S. A, 2000. p. 25. 
comunidade hoje também pode ser referida como imensas redes de pessoas que se aproximam (às vezes só virtualmente) por aquilo que as afetam e naquilo que elas compartilham, porquanto que somente por meio da transmissão de valores se dará a construção de novas comunidades (ou sociedades) que referendam o espaço emancipador e igualitário do papel da mulher no mundo ocidental.

\section{A HISTÓRIA (SEGREGADA) DA MULHER: ALGUMAS NOTAS}

A história das mulheres começou por inventar-se, pois, enquanto os homens entravam para o mundo do registro e da interpretação dos acontecimentos no milênio terceiro A.C, para as mulheres esse processo só correu no século XIX ${ }^{36}$. É assim que as primeiras linhas da obra de Miles denunciam a completa segregação da história da mulher no mundo. E vai além:

A história da raça humana começa com a fêmea. A mulher carregou o cromossomo humano original, como faz até hoje; sua adaptação evolutiva garantiu a sobrevivência e o sucesso da espécie; sua tarefa de maternidade forneceu o estímulo cerebral necessário à comunicação humana e à organização social. No entanto, para as gerações historiadores, arqueólogos, antropólogos e biólogos, a única estrela da aurora tem sido o homem ${ }^{37}$ (Grifo nosso).

Até meados do século passado, a maior parte dos teóricos homens, de todos os pontos do espectro político, aceitava a crença de que havia um fundamento natural para o confinamento da mulher à família e para sua sujeição ao marido, bem como eram inaptas às atividades políticas ${ }^{38}$. Enquanto a genialidade masculina era escrita, deixava-se de considerar a realidade da maioria das vidas femininas, sendo que "a exclusão da mulher dos anais representa um milhão de milhões de vozes sufocadas" ${ }^{\prime 39}$.

36 MILES, Rosalind. A história do mundo pelas mulheres. Trad. Bárbara Heliodora. Rio de Janeiro: LTC, 1989.

37 MILES, Rosalind. A história do mundo pelas mulheres. Trad. Bárbara Heliodora. Rio de Janeiro: LTC, 1989. p. 19.

38 KYMLICKA, Will. Filosofia política contemporânea. Trad. Luiz Carlos Borges. São Paulo: Martins Fontes, 2006.

39 MILES, Rosalind. A história do mundo pelas mulheres. Trad. Bárbara Heliodora. Rio de Janeiro: LTC, 1989. p. 10. 
As comunidades tradicionais mencionadas no ponto inicial mantinham em seu âmago a opressão à mulher, velando as funções de líder, de chefe, de deusa, ${ }^{40}$ enfim, dos papéis da mulher no seio da comunidade. Reis e Costa se posicionam ao tema, revelando que, desde muito cedo, foi incutido nas meninas que era incumbência delas cuidar da casa e dos filhos, enquanto os homens eram os responsáveis pelo sustento da família, cabendo a eles sair de casa e ir para o trabalho, participar da vida produtiva da sua comunidade, receber salário e administrar os bens da família ${ }^{41}$.

E quanto à sociedade atual? Para Silveira ${ }^{42}$, a partir dos séculos XVIII e XIX, com a compreensão da distinção anatômica entre corpo feminino e corpo masculino, operou-se uma divisão pela qual as mulheres passaram a ser consideradas como parte da natureza; e os homens, parte da cultura. Tal divisão se deu por meio das associações simbólicas entre o corpo feminino e o ato de procriar, conceber e amamentar. Ao mesmo tempo, o corpo masculino era associado ao mundo em transformação, à racionalidade, ao desenvolvimento. E é importante assinalar que tal binarismo de gênero apresenta não só uma relação de oposição, mas também demonstra uma hierarquia, percebida facilmente na sociedade e que vem se perpetuando ao longo dos anos ${ }^{43}$. O modo como a anatomia do indivíduo é revestida é que define o sujeito de gênero e não propriamente o corpo e, nesse sentido, para Porto e Costa ${ }^{44}$, os papéis sociais do feminino e do masculino são construídos culturalmente pelo poder simbólico dominante e masculino, que se reproduz e se perpetua nas relações entre os gêneros no âmbito privado e no espaço público.

40 Na pré-história, Deus era uma mulher, e os habitantes sumerianos, onde hoje esta o Iraque, adoravam-na cantando hinos de louvores aos seus dotes sexuais e também pela fúria guerreira que seu poder e centralidade emergiam (MILES, 1989).

41 REIS, Suzéte Silva; COSTA, Marli Marlene Moraes da. Trabalho, educação \& gênero: desafios e perspectivas da inserção da mulher no mercado de trabalho no século XXI [recurso eletrônico]. Curitiba: Multideia, 2014. p. 34.

42 SILVEIRA, Clara Maria Holanda. A mulher é Eva, o homem é Adão? Reflexões sobre o significado de ser homem e de ser mulher na sociedade. Caderno Espaço Feminino - Uberlândia-MG - v. 27, n. 1 - Jan/Jun. 2014 - ISSN on-line 1981-3082.

43 BARROSO, Rafael Chaves Vasconcelos; FARIAS, Francisco Ramos de. GÊNERO E MEMÓRIA: uma construção dionisíaca. Caderno Espaço Feminino - Uberlândia-MG - v. 27, n. 1 - Jan/Jun. 2014 - ISSN online 1981-3082.

44 PORTO, Rosane Teresinha Carvalho; COSTA, Marli Marlene Moraes da. Justiça Restaurativa \& Gênero: por uma humanização que desarticule a violência [recurso eletrônico]. Curitiba: Multideia, 2014. p. 19. 
Neste século, as novas tecnologias, assim como progressos na ciência médica e urbanização, vêm oferecendo à mulher liberdade sem igual - porém cada um desses itens traz em seu bojo sementes de seu uso contra a mulher, novas oportunidades para degradação e exploração, novas formas de trabalho destruidor pela rotina, novos ataques contra a vida e a esperança ${ }^{45}$. Tais explorações são alvo de inúmeras conquistas que iniciaram no século $X X$, com movimentos organizados feministas e um olhar mais acurado do Estado para as questões de equidade de gênero no que tange às políticas sociais.

Do amplo espectro de teorias políticas contemporâneas, boa parte compartilha um norte por igualdade em seu teor, ou, como expõe Kymlicka, tais teorias contemplam:

[...] um compromisso com a ideia de que todos os membros da comunidade devem ser tratados como iguais. Contudo, até bem recentemente, a maior parte da filosofia política dominante defendeu ou, pelo menos, aceitou a discriminação sexual. E, embora as visões tradicionais a respeito da discriminação sexual tenham sido progressivamente abandonadas, muitas feministas acreditam que os princípios que foram desenvolvidos com a experiência e os interesses dos homens em mente são incapazes de reconhecer adequadamente as necessidades das mulheres ou de incorporar as experiências das mulheres ${ }^{46}$ (Grifo nosso).

A ideia de que os indivíduos são proprietários em suas pessoas tem sido fundamental na luta contra a dominação classista e patriarcal. Isso tem motivado muitas campanhas feministas, desde os esforços pela modificação da legislação matrimonial até as questões relacionadas ao aborto. Tal fato mostra-se importante, pois a doutrina legal de séculos determinou que as mulheres fossem propriedades de seus maridos, cujo "argumento apoiava-se, portanto, numa rejeição implícita da construção patriarcal do indivíduo como proprietário masculino"47.

Ao longo de boa parte do século XX, o Brasil conviveu com os princípios discriminatórios e patriarcais do Código Civil de 1916. Foi um século em que as 45 MILES, Rosalind. A história do mundo pelas mulheres. Trad. Bárbara Heliodora. Rio de Janeiro: LTC, 1989. p. 13.

46 KYMLICKA, Will. Filosofia política contemporânea. Trad. Luiz Carlos Borges. São Paulo: Martins Fontes, 2006. p. 304.

47 PATEMAN, Carole. O contrato sexual. Rio de Janeiro: Paz e Terra. 1993. p. 32. 
relações se fragmentaram. Somente com a Constituição Federal de 1988 consagrouse a igualdade entre homens e mulheres como um direito fundamental. O princípio da equidade entre os gêneros foi endossado no âmbito da sociedade e da família, neste caso, quando o texto estabelece que os direitos e os deveres referentes à sociedade conjugal são exercidos igualmente pelos homens e pelas mulheres ${ }^{48}$. As definições constitucionais foram gradativamente convertidas em legislação ordinária, cujo desdobramento deu-se em inúmeras normativas, como o Estatuto da Criança e do Adolescente (Lei n. 8.069 de 13/07/1990), a Lei do Concubinato (Lei n 8.971) de 29/12/1994, a Lei do Planejamento Familiar (Lei 9.263/1996), o Estatuto do Idoso (Lei n. 10.741 de 01/10/2003) e o novo Código Civil brasileiro (Lei 10.406, de 10/1/2002) ${ }^{49}$.

Um dado brasileiro e atual importante foi relevado por um estudo do IPEA, que avaliou o impacto da Lei Maria da $P_{e n h a^{50}}$ sobre a mortalidade de mulheres por agressões, por meio de estudos de séries temporais. Constatou-se que não houve impacto, ou seja, não houve redução considerável das taxas anuais de mortalidade, comparando-se os períodos antes e depois da vigência da Lei. As taxas de mortalidade por 100 mil mulheres foi de 5,28 no período 2001-2006 (antes) e 5,22 em 2007-2011 (depois). Observou-se sutil decréscimo da taxa no ano 2007, imediatamente após a vigência da Lei e, nos últimos anos, o retorno desses valores aos patamares registrados no início do período ${ }^{51}$. A realidade da Maria da Penha dá conta do quão imprescritível é o papel dos movimentos sociais para o fortalecimento da participação maior da mulher nas decisões políticas e na superação da discriminação do trabalho e na erradicação das mazelas que

48 ALVES, José Eustáquio Diniz; CAVENAGHI Suzana Marta. Dossiê - análises quantitativas e indicadores sociais: indicadores de desigualdade de gênero no brasil. mediações, Londrina, V. 17 N. 2, p. 83-105, JUL./DEZ. 2012.

49 ALVES, José Eustáquio Diniz; CAVENAGHI Suzana Marta. Dossiê - análises quantitativas e indicadores sociais: indicadores de desigualdade de gênero no brasil. mediações, Londrina, V. 17 N. 2, p. 83-105, JUL./DEZ. 2012.

50 A biofarmacêutica Maria da Penha Maia ficou paraplégica depois de ser atingida por um tiro pelas costas. O ano era 1983 e o atirador era Marco Antonio Heredia: o marido de Maria da Penha. A biofarmacêutica iniciou uma luta de mais de 20 anos para que Marco Antonio fosse punido por seu crime. Em 2001, a Comissão Interamericana de Direitos Humanos condenou o Brasil por negligência em relação à violência doméstica. Em 2003, o ex-marido de Maria da Penha finalmente foi preso. O caso provocou grande repercussão e levou o governo brasileiro a sancionar a Lei da Violência doméstica e familiar contra a mulher, que ficou conhecida como Lei Maria da Penha (BORELLI, 2013)

51 GARCIA, Leila Posenato et al. Violência contra a mulher: feminicídios no Brasil. Instituto de Pesquisa Econômica Aplicada - Ipea. Texto digital. In. www.ipea.gov.br. Acesso em 09 de novembro de 2014 . 
ambientam a sua sexualidade ${ }^{52}$. O que isso significa? Que a matriz legiferante pode apertar o cerco contra as questões afetas às mulheres, porém não serão as leis, isoladamente, as propulsoras de uma guinada na cena desigual do tema.

O combate às desigualdades e, especialmente, à discriminação, requer atitudes não só punitivas, mas também atos que construam uma nova cultura política na sociedade, e esse trabalho é, de fato, árduo e contínuo. Aos governos cabe fazer cumprir a norma constitucional de igualdade e não discriminação reiterada pelas diversas convenções internacionais ratificadas pelo Brasil ${ }^{53}$ e cabe, ainda, a implementação de políticas que corrijam as desigualdades historicamente construídas, bem como sejam oferecidas iguais oportunidades para homens e mulheres, negros e brancos, mas sempre respeitando suas diferenças, contribuindo para a modificação do padrão cultural vigente, que ainda enxerga os negros e as mulheres em escala inferior na hierarquia de poder social ${ }^{54}$.

Ainda nesse mote é preciso referir que os estatutos legais não propiciam a antidiscriminação e arrisca-se dizer, não fomentam a igualdade dos sexos. Não se está aqui criticando sua existência, pelo contrário, está-se constatando apenas que, embora a abordagem legal da diferença encampada pelo mundo ocidental tenha gerado sucessos, como permitir acesso às ocupações que os homens sempre tiveram livremente, ela, ao mesmo tempo, ignora a desigualdade embutida nos cargos e nas posições. Os avanços que as mulheres brasileiras conseguiram na educação ${ }^{55}$, no mercado de trabalho, nos esportes, na previdência

52 CORRÊA, Lindinalva Rodrigues. Direitos humanos das mulheres: doutrina, prática e direito comparado. 2reimp. Curitiba: Juruá, 2012.

53 Segundo o Relatório anual socioeconômico de 2013, no âmbito internacional a promoção dos direitos das mulheres ganhou mais ênfase a partir de 1975, com a criação do Ano Internacional das Mulheres. Na Cidade do México foi realizada a Conferência das Nações Unidas para as Mulheres. O Brasil participou de todas as conferências internacionais das Nações Unidas, cujo tema foram os direitos das mulheres e assinou os documentos resultantes dessas conferências, o que ressalta o compromisso do Estado brasileiro na promoção da igualdade de gênero [...]. Atualmente, está em vigor o PNPM (2013-2015), que representa o terceiro plano elaborado com base nas demandas das CNPM por políticas públicas voltadas à garantia de direitos das mulheres. O PNPM reúne de forma articulada as diversas políticas do governo federal voltadas para as mulheres, associando-as às previsões do Plano Plurianual (PPA) (BRASIL, p. 140-141)

54 IPEA. Instituto de Pesquisa Econômica Aplicada. Retrato das Desigualdades. 2. ed. Luana Pinheiro et al. Programa Igualdade de Gênero e Raça UNIFEM. Diretoria de Estudos Sociais. In: Programa Igualdade de Gênero e Raça. unifemgeneroraca@undp.org.br.

55 Segundo estudos recentes publicados, nas gerações mais jovens as mulheres conseguiram superar os homens no ensino fundamental e, especialmente, no ensino médio e superior. Neste 
e na sociedade ainda não se traduziram em aumentos significativos nas diversas esferas dos espaços de poder ${ }^{56}$ público e privado ${ }^{57}$. A educação tanto pode servir de instrumento para a manutenção e para a perpetuação das concepções e dos paradigmas vigentes, como para transformá- $\operatorname{los}^{58}$. E, ademais, como a educação está para servir aos interesses da sociedade, por intermédio da transmissão dos valores culturais e historicamente aceitos, ela é organizada a partir de bases que sustentam o modelo e as concepções vigentes ${ }^{59}$.

Assim, a solução:

[...] não é apenas a ausência de discriminação, mas a presença de poder. A igualdade requer não apenas igual oportunidade de buscar papeis definidos por homens, mas também igual poder de criar papeis definidos por mulheres ou de criar papeis andrógenos, que homens e mulheres tenham igual interesse em preencher. ${ }^{60}$ (Grifo nosso).

\section{A criação de papéis referida está contida na transformação cultural na busca} pelo rompimento de uma visão "binária" de comunidade, de espaços e de

último, 60\% dos formandos são do sexo feminino. Mais recentemente, a partir de 2004, as muIheres são maioria também entre os titulados dos cursos de doutorado no Brasil (IBGE, 2014).

56 Contudo, lembram muito bem Alves e Cavenagui, que houve uma grande novidade no ano de 2010, (replicada neste ano de 2014), pois o Brasil elegeu a primeira mulher para a Presidência da República, cargo máximo do poder público do país. Esta eleição não deixa de ser surpreendente, pois o Brasil tem uma das participações mais baixas do mundo de mulheres na Câmara Federal de deputados (ocupa o $140^{\circ}$ no ranking mundial da participação política - IPU/2010). A eleição de Dilma Rousseff colocou o Brasil entre o seleto clube de 16 países que possuem mulheres no comando máximo da política. A presidenta Dilma indicou nove mulheres para o ministério, as quais tomaram posse em $01 / 01 / 11$. As nove mulheres no primeiro escalão, entre 37 ministros, significa um espaço de $24 \%$ para o sexo feminino, o que é um recorde histórico para os padrões brasileiros. Contudo ficou muito abaixo da meta de um gabinete paritário, que é objetivo da campanha 50/50 (Women's Lobby 50/50 Campaign for Democracy). Já na América Latina foi aprovado, em 2007, o chamado "Consenso de Quito", que foi um acordo que o Brasil assinou na $10^{a}$ Conferência Regional sobre a Mulher da América Latina e do Caribe, ocorrida no Equador. Nesta Conferência regional foi reforçada a ideia de que a paridade de gênero é essencial para o desenvolvimento e a democracia (ALVES; CAVENAGUI, 2013).

57 ALVES, José Eustáquio Diniz; CAVENAGHI Suzana Marta. Dossiê - análises quantitativas e indicadores sociais: indicadores de desigualdade de gênero no brasil. mediações, Londrina, V. 17 N. 2, p. 83-105, JUL./DEZ. 2012.

58 REIS, Suzéte Silva; COSTA, Marli Marlene Moraes da. Trabalho, educação \& gênero: desafios e perspectivas da inserção da mulher no mercado de trabalho no século XXI [recurso eletrônico]. Curitiba: Multideia, 2014. p. 47.

59 REIS, Suzéte Silva; COSTA, Marli Marlene Moraes da. Trabalho, educação \& gênero: desafios e perspectivas da inserção da mulher no mercado de trabalho no século XXI [recurso eletrônico]. Curitiba: Multideia, 2014. p. 57.

60 KYMLICKA, Will. Filosofia política contemporânea. Trad. Luiz Carlos Borges. São Paulo: Martins Fontes, 2006. p. 313. 
pessoas. Já se sabe que uma mirada de valores (e não de leis!) modificaria, por exemplo, a comunidade mais antiga, que é a família, a não mais retroalimentar a dependência econômica, vinculando a mulher ao papel em seu núcleo. A noção de gênero, ainda criticada, "permitió en su contexto una reflexión profunda sobre las nociones de naturaleza y cultura. La irrupción de la categoría de género obligó a revisar ciertas miradas unívocas y esencialistas que los estudios sobre mujeres habían tenido hasta ese momento. ${ }^{61}$

Para Sennett, é aqui que a cultura entra em cena:

[...] E falo de "cultura" em sentido antes antropológico que artístico. Quais os valores e práticas capazes de manter as pessoas unidas no momento em que as instituições em que vivem se fragmentam? Minha geração demonstrou falta de imaginação ao tentar responder a esta pergunta, preconizando as virtudes da comunidade de pequeno tamanho. A comunidade não é a única maneira de manter coesa uma cultura; parece evidente, por exemplo, que os estranhos de uma mesma cidade convivem numa mesma cultura, ainda que não se conheçam pessoalmente. Mas o problema de uma cultura que realmente nos sirva de base não se limita a uma questão de tamanho. Só um certo tipo de ser humano é capaz de prosperar em condições sociais instáveis e fragmentárias. Este homem ou mulher ideal tem de enfrentar três desafios. ${ }^{62}$ (Grifo nosso).

Dos desafios a que se refere Sennett, o primeiro é o tempo; o segundo é o talento; e o terceiro, a possibilidade de deixar o passado para trás. Este último, para esta breve pesquisa, é o fecho: além dos desafios da (re)construção de uma cultura política, a possibilidade de se desprender ainda é a maior e, teoricamente, inalcançável. A vivência de uma colonização cujos ensinamentos são passados sem questionamentos fizeram perpetuar o papel secundário da mulher na sociedade e, indo mais além, é também o motivo pelo qual ainda nos dias de hoje a mutilação genital feminina é uma prática vigente em 29 países do mundo. Segundo uma organização mundialmente conhecida, 150 milhões de mulheres têm a vagina mutilada anualmente e, segundo a ONU, até 2030, outras 86 milhões podem ser cortadas, segundo a Desert Flower Foundation (2014).

61 VALOBRA, Adriana María. Los caminos de la historia de las mujeres y de género. In: Fronteiras de gênero. Organizadoras: Joana Maria Pedro, Silvia Maria Fávero Arend, Carmem Sílvia de Moraes Rial. Florianópolis: Ed. Mulheres, 2011. p. 28.

62 SENNETT, Richard. A cultura do novo capitalismo. Tradução Clóvis Marques. Rio de Janeiro: Record, 2006. p. 13. 
Veja-se que alguns pontos são cruciais. A urgência em retificar as desigualdades que abalam o bem-estar das mulheres e as sujeitam a um tratamento desigual advém também do papel da condição de agente. O desenvolvimento econômico, humano e social contribui, naturalmente, para o bem-estar feminino e, para tal, todos, indistintamente, devem assumir a responsabilidade ${ }^{63}$. Ou seja, para Sen, "deve ser dada atenção à ampla evidência de que a democracia e os direitos políticos e civis tendem a reforçar as liberdades de outros tipos (como a segurança humana) ao dar voz, pelo menos em muitas circunstâncias, aos carentes e vulneráveis." ${ }^{64}$. A democracia possibilita à oposição oportunidade de pressionar por mudanças políticas.

As mulheres não querem criar por parte delas mesmas um novo modelo cultural, segundo Touraine. O que querem é um novo modelo de cultura, mas que deve ser vivido por todos, homens e mulheres, eliminando a "oposição" e não estabelecendo hierarquia ${ }^{65}$. A nova cultura:

[...] conduzida pelas mulheres, não busca nem excluir nem colocar os homens numa posição inferior, mas pretende que todos harmonizem o que tinha sido separado e marcado pela pecha da superioridade ou da inferioridade. Essa cultura nova busca recompor a experiência pessoal e coletiva, e igualmente unir o que tinha sido separado ${ }^{66}$.

Para Sen ${ }^{67}$, os movimentos feministas foram cruciais para o incremento de maior participação política por meio de práticas de associação civil, tão valorosos a partir do século XX. Como explica Gohn, "as práticas culturais podem ser desenvolvidas em duas frentes: na sociedade civil - via manifestações culturais ou associativas que possibilitem a articulação das singularidades existentes; e na sociedade política - via politicas públicas" ${ }^{68}$. E a despeito das políticas públicas,

63 SEN, Amartya. Desenvolvimento como liberdade. Tradução Laura Teixeira Motta. São Paulo: Companhia das Letras, 2000.

64 SEN, Amartya. Desenvolvimento como liberdade. Tradução Laura Teixeira Motta. São Paulo: Companhia das Letras, 2000. p. 383.

65 TOURAINE, Alain. O Mundo das mulheres. Petrópolis: Vozes, 2011.

66 TOURAINE, Alain. O Mundo das mulheres. Petrópolis: Vozes, 2011. p. 106.

67 SEN, Amartya. Desenvolvimento como liberdade. Tradução Laura Teixeira Motta. São Paulo: Companhia das Letras, 2000.

68 GOHN, Maria da Glória. O protagonismo da sociedade civil: movimentos sociais, ONGs e redes solidárias. 2 ed. São Paulo: Cortez, 2008. p. 46. 
Costa $^{69}$ referenda que elas devem ser transversais, o que se traduz na ideia de ampliação dos atores sociais na formulação de políticas públicas, incluindo-se nelas a perspectiva de gênero.

E a autora explica como se dá esse processo:

Em virtude disso, a transversalidade de gênero na gestão das políticas públicas deve atuar, ao mesmo tempo, em três aspectos: promovendo a articulação interseccionadas ações nas políticas sociais federais; proporcionado a cooperação nas três esferas do governo (federal, estadual e municipal) e, promovendo o estímulo à cooperação entre os agentes e as instituições das esferas pública e privada, de modo a fomentar a participação ativa de todos os cidadãos no enfrentamento à violência contra a mulher. ${ }^{70}$

Ademais, a promoção da transversalidade de gênero por meio da construção de Planos vem se disseminando nos demais níveis de governo. Em 2012, 37\% dos estados brasileiros possuíam planos estaduais de políticas para as mulheres, o que indica a ampliação dos compromissos do país com a promoção da igualdade de gênero ${ }^{71}$.

Portanto faz parte da contemporaneidade a luta pelos direitos iguais, contra a discriminação e a segregação entre os sexos, pelo reconhecimento e pelo respeito da paridade e da isonomia nos espaços de poder, ou seja, pela equidade de gênero. Até agora as vitórias foram parciais, mas foram conquistas acumulativas e irreversíveis. Os indicadores sociais e demográficos do país mostram que houve redução de algumas desigualdades de gênero e reversão de outras, mas ainda falta muito para o Brasil chegar a uma justa e plena situação de equidade de gênero ${ }^{72}$.

69 COSTA, Marli Marlene Moraes da. A transversalidade das políticas públicas na perspectiva de gênero. In: COSTA, Marli M. M. da; LEAL, Mônia Clarissa Henning. Direitos sociais e políticas públicas: desafios contemporâneos. Tomo 13, Santa Cruz do Sul: EDUNISC, 2013.

70 COSTA, Marli Marlene Moraes da. A transversalidade das políticas públicas na perspectiva de gênero. In: COSTA, Marli M. M. da; LEAL, Mônia Clarissa Henning. Direitos sociais e políticas públicas: desafios contemporâneos. Tomo 13, Santa Cruz do Sul: EDUNISC, 2013. p. 208.

71 BRASIL. Presidência da República. Secretaria de Políticas para as Mulheres. Relatório Anual Socioeconômico da Mulher. $1^{a}$ Impressão. Brasília: Secretaria de Políticas para as Mulheres, Novembro, 2013.

72 ALVES, José Eustáquio Diniz; CAVENAGHI Suzana Marta. Dossiê - análises quantitativas e indicadores sociais: indicadores de desigualdade de gênero no brasil. mediações, 


\section{A NOVA MULHER E A NOVA COMUNIDADE (?)}

Em fala atual sobre cultura política de gênero, Ribeiro ${ }^{73}$ coloca que, para parte dos analistas, o fenômeno da sub-representação feminina deve ser entendido a partir de uma "perspectiva multicausal", na medida em que o poder masculino foi sendo legitimado pelas instituições e a visão androcêntrica se impôs em detrimento da competência feminina. Inúmeras foram as lutas femininas engendradas para subverter tal ordem imposta pelos homens ${ }^{74}$. Ou seja, por mais destaque nas agendas políticas ${ }^{75}$ atuais, a perspectiva de tratamento e reconhecimento igualitário de gênero ainda é fenômeno a ser trabalhado sob múltiplos aspectos, fatores e disposições políticas, pois a eficácia das políticas públicas de gênero depende, em grande medida, de se compreender o reconhecimento cultural do país. Em muito se avançou, graças a esforços coletivos de todas as frentes.

Segundo dados colhidos pela Secretaria de Políticas para as Mulheres e apresentados à sociedade brasileira por meio do Relatório Anual Socioeconômico da Mulher (RASEAM) em 2013, um cenário demográfico importante no aspecto político e social de colocação da mulher e do papel dela no Brasil se desenha hoje: ao mesmo tempo em que a expectativa de vida aumenta, também a chefia feminina nas famílias atinge valores ainda mais elevados nas zonas urbanas, próximo ou superior a $40 \%$ do total. Nas últimas décadas, ampliou-se a participação feminina no mercado de trabalho ${ }^{76}$, todavia a construção da igualdade plena entre homens

Londrina, V. 17 N. 2, p. 83-105, JUL./DEZ. 2012.

73 RIBEIRO, Ednaldo Aparecido. Cultura Política e Gênero no Brasil: Estudo exploratório sobre as bases da sub-representação feminina. IV Congresso Latino Americano de Opinião Pública da WAPOR, Belo Horizonte - BrasilAT 08 Opinião Pública, Cultura Política e Democracia, 2014. In: www.revista.ufpe.br/politicahoje/index.php/politica/article/.../220 de EA Ribeiro - 2014.

74 COSTA, Marli Marlene Moraes da; D'Oliveira, Mariane Camargo. Idiossincrasias femininas [recurso eletrônico] - Curitiba: Multideia, 2013. p. 89.

75 A sub-representação das mulheres no sistema político das democracias contemporâneas adquiriu, nas últimas décadas, um lugar de destaque na agenda de organizações da sociedade civil, instâncias do Estado, agências multilaterais e pesquisas acadêmicas. Dados produzidos por diferentes organismos internacionais, como o Inter-Parliamentary Union (IPU), o Fórum Econômico Mundial (FEM) e a Comissão Econômica para a América Latina (CEPAL), indicam um quadro negativo em termos de igualdade política entre homens e mulheres no cenário global, ainda que mudanças importantes venham ocorrendo nas últimas décadas, em especial nas nações economicamente desenvolvidas (RIBEIRO, 2013).

76 Em 1950, a População Economicamente Ativa (PEA) feminina era de 13,6\%; em 1970, 
e mulheres no mundo do trabalho não se consolidou, e isso se deve em muito pelo acúmulo funcional duplo: produtivo e reprodutivo.

E nesse sentido, o Relatório Demográfico expõe que:

[...] nas desigualdades de rendimentos, possibilidades de acesso à carreira e dupla jornada de trabalho, que acumula o trabalho produtivo e o reprodutivo. As tarefas domésticas e de cuidados permanecem sendo atribuição majoritariamente feminina, o que tem diversas implicações nas possibilidades de emprego e no exercício de outras atividades, como educação, participação em associações e partidos, lazer e cuidado de $\mathrm{si}^{\mathrm{i}}$.

O texto apresenta um paralelo cruel trazido pela modernidade: as variáveis que afetam o bem-estar dizem respeito ao trabalho fora de casa (auferindo mais renda), ao mesmo tempo em que há a sobrecarrega na vida em casa. Os afazeres domésticos culturalmente são identificados como uma labuta feminina. Há que se reconhecer que a nova mulher é, na realidade, uma "super" mulher ambientada numa sociedade em que os avanços legais foram muitos, mas a qual segue os parâmetros das comunidades tradicionais. Assim, é necessário pensar em uma inserção qualificada das mulheres no mercado de trabalho, de modo que o preceito constitucional de igualdade entre os gêneros, na seara do trabalho, efetivamente se concretize. A qualificação profissional é um dos caminhos para se alcançar a igualdade nas condições de trabalho. ${ }^{78}$

Outro fator é o papel limitado da condição de agente ativa das mulheres afetando gravemente a vida de todas as pessoas ${ }^{79}$. O histórico alijamento das mulheres das esferas de poder e decisão é um obstáculo à plena consolidação da democracia no país ${ }^{80}$. Como se pode verificar, as práticas patriarcais continuam

alcançou 18,5\%; em 1991, 32,9\%; e, em 2000, 44,1\% (CENSOS DEMOGRÁFICOS/IBGE apud ALVES, 2013). (BRASIL, 2013)

77 BRASIL. Presidência da República. Secretaria de Políticas para as Mulheres. Relatório Anual Socioeconômico da Mulher. $1^{\text {a }}$ Impressão. Brasília: Secretaria de Políticas para as Mulheres, Novembro, 2013. p. 29.

78 REIS, Suzéte Silva; COSTA, Marli Marlene Moraes da. Trabalho, educação \& gênero: desafios e perspectivas da inserção da mulher no mercado de trabalho no século XXI [recurso eletrônico]. Curitiba: Multideia, 2014. p. 50.

79 SEN, Amartya. Desenvolvimento como liberdade. Tradução Laura Teixeira Motta. São Paulo: Companhia das Letras, 2000. p. 222.

80 BRASIL. Presidência da República. Secretaria de Políticas para as Mulheres. Relatório Anual 
a associar os espaços de poder como sendo masculinos e a sobrecarregar as mulheres com as tarefas domésticas e de cuidado, assim como bloquear sua ascensão nas carreiras e nos ofícios, o que denota outro fator de cunho cultural que a feitura de lei não consegue dar conta.

O trabalho de pesquisa exploratório sobre valores e com base no Projeto Pesquisa Mundial de Valores (World Values Survey - WVS) demostra que a luta pela igualdade política entre os gêneros ainda esbarra na persistência de concepções e nos valores relativamente desfavoráveis. Mesmo com a perceptível mudança cultural no que diz respeito aos papéis e às atribuições de cada gênero em diferentes esferas da vida social, é preocupante que "[...] mais de um terço da população nacional considere ainda que os homens são melhores líderes políticos simplesmente por serem homens" ${ }^{11}$.

A participação econômica das mulheres é tanto uma recompensa em si (com a redução associada ao viés contra o sexo feminino na tomada de decisões familiares) como uma grande influência para a mudança social em geral, e sua autonomia financeira é um dos principais mediadores da transformação econômica e social, relacionando-se estreitamente a muitas das características centrais do processo de desenvolvimento. ${ }^{82}$

Ao se proporem políticas públicas que promovam o empoderamento das mulheres para que transformem seu futuro, está-se dando um passo muito importante em direção à desobstaculização de muitas das práticas discriminatórias ainda existentes. Apesar dos relevantes avanços em áreas cruciais, é essencial fazer mais. Isso porque a maioria das mulheres brasileiras, especialmente as mais pobres, rurais, negras e indígenas, continua vivenciando situações de exclusão, de miséria e de violência. ${ }^{83}$.

Socioeconômico da Mulher. $1^{a}$ Impressão. Brasília: Secretaria de Políticas para as Mulheres, Novembro, 2013.

81 BRASIL. Presidência da República. Secretaria de Políticas para as Mulheres. Relatório Anual Socioeconômico da Mulher. $1^{a}$ Impressão. Brasília: Secretaria de Políticas para as Mulheres, Novembro, 2013.

82 SEN, Amartya. Desenvolvimento como liberdade. Tradução Laura Teixeira Motta. São Paulo: Companhia das Letras, 2000.

83 COSTA, Marli Marlene Moraes da; D'Oliveira, Mariane Camargo. Idiossincrasias femininas [recurso eletrônico] - Curitiba: Multideia, 2013. p. 89. 
No entanto a mudança nesse quadro é papel também dos demais atores que compõem a sociedade brasileira. Cabe aos movimentos sociais ${ }^{84}$ pressionar por uma atuação política que combata o sexismo e o racismo; ao Legislativo oferecer os instrumentos legais necessários à construção da igualdade; e ao Judiciário, a responsabilização e a punição daqueles que praticam atos discriminatórios. Se a discriminação é um processo socialmente construído, cabe a cada um a responsabilidade pela sua desconstrução ${ }^{85}$, mas é papel romper paradigmas: a nova mulher numa velha comunidade.

Por seu turno, o empoderamento comunitário é o processo pelo qual os sujeitos de uma comunidade, por meio de processos participativos, constroem estratégias e ações para atingir seus objetivos, coletiva e consensualmente traçados, sendo uma resultante de tensões e conflitos por recursos ${ }^{86}$. Para Etzioni, a tarefa é buscar unir as questões de tradição com elementos notáveis da modernidade:

[...] a tarefa comunitária, tal como a vejo, é encontrar uma maneira de combinar elementos de tradição (uma ordem baseada nas virtudes) com elementos de modernidade (uma autonomia bem protegida). Isto implica falar em um equilíbrio entre os direitos individuais universais e o bem comum (que frequentemente se veem como conceitos incompatíveis), entre EU e a comunidade, e, sobretudo, a maneira se sustentar este equilíbrio ${ }^{87}$.

É de se falar que se devem manter as tradições naquilo que sustentam de positivo e coerente com a moderna maneira de viver em comunidade e, em relação às questões de gênero, uma comunidade globalizada, interligada e que convive com ações autonomizadoras e emancipadoras nos esforços educativos, nas políticas públicas do Executivo, nas leis genitoras de oportunidades iguais

84 Na verdade, o componente feminino nos movimentos sociais foi dos mais significativos. A indiscutível supremacia das mulheres nos movimentos comunitários, de forma primordial entre as populações mais economicamente periféricas, tem sido um importante canal de conscientização de direitos de cidadania.

85 IPEA. Instituto de Pesquisa Econômica Aplicada. Retrato das Desigualdades. 2a edição Luana Pinheiro(et al.). Programa Igualdade de Gênero e Raça UNIFEM. Diretoria de Estudos Sociais. In: Programa Igualdade de Gênero e Raça unifemgeneroraca@undp.org.br. p. 58.

86 COSTA, Marli Marlene Moraes da; D'Oliveira, Mariane Camargo. Idiossincrasias femininas [recurso eletrônico] - Curitiba: Multideia, 2013. p. 98.

87 ETZIONI, Amitai. La nueva regla del oro: comunidad y moralidad em uma sociedad democrática. Barcelona: Paidós, 1999. p. 18. 
do Legislativo e de múltiplas faces da sociedade civil organizada, que luta incansavelmente para a mulher ser reconhecida politicamente, valorizada socialmente e portadora de um protagonismo de igual medida na gestão dos interesses que lhe afetam diretamente.

Sobre o nível e a qualidade do empoderamento, ligado ao aqui trabalhado sobre a perspectiva de uma nova consciência de mulher, é importante realçar que a mulher deve também ser responsável pela mudança. Muitas mulheres reproduzem pensamentos machistas, às vezes até de maneira insciente e, por outras, teorizam uma possível emancipação, mas, na prática, são amalgamadas por pequenos atos rotineiros de autoexclusão. Nesse sentido, sobre 'experenciar' o empoderamento, Costa e D’Oliveira expõem:

As mulheres podem tornar-se poderosas sem que haja efeitos positivos nas outras mulheres ou na ordem social; elas podem experimentar empoderamento pessoal, mas podem descobrir que muito em sua vida não é possível de ser corrigido pela mudança; mediante seu agenciamento individual e as mudanças sociais que favorecem o empoderamento feminino, podem acontecer sem o engajamento ativo das mulheres. Entretanto, é indispensável fomentar, no cotidiano, práticas sociais includentes, sendo que o empoderamento é uma delas. É essencial secundarizar a passividade e engendrar o processo de empoderamento, traduzindo a autonomia em uma conquista pragmática efetiva e contínua. O empoderamento configura-se, sim, como um catalisador da inclusão social e, dessa forma, se constitui como desafio contemporâneo ${ }^{88}$.

Em que pese tais esforços, ao se perpetuarem as negligências centenárias na criação dos filhos, as conquistas intelectuais e políticas que até agora lograram êxito de nada adiantarão, pois estarão baseadas em um fundamento inseguro, e além e mais que isso, "qualquer teoria adequada da igualdade sexual DEVE confrontar as questões e as concepções tradicionais de discriminação e privacidade que as ocultam"89. A dimensão do novo deve perpassar, como já referido, os ranços e as privações tradicionais, tanto no que refere à nova comunidade, como de fato

88 COSTA, Marli Marlene Moraes da; D'Oliveira, Mariane Camargo. Idiossincrasias femininas [recurso eletrônico] - Curitiba: Multideia, 2013. p. 111.

89 KYMLICKA, Will. Filosofia política contemporânea. Trad. Luiz Carlos Borges. São Paulo: Martins Fontes, 2006. p. 373. Grifo nosso. 
ao delinear a nova mulher, emancipada e autonomizada. Uma nova comunidade deve estar ligada a uma nova mentalidade, a novos olhos e à construção de uma sociedade mais vigorosa e creditada na diversidade e na cidadania.

\section{CONSIDERAÇÕES FINAIS}

O estudo ocupou-se do tema de gênero, permeando as comunidades tradicionais e as sociedades atuais para referir que seguem desiguais os papéis sociais, embora muito se tenha alcançado de prospectivo e de luta contra a secundarização dos escritos da história sobre a ideia de mulher e suas múltiplas funções esquecidas. Uma nova comunidade deve contemplar uma mentalidade nova e uma visão ampliada do seu entorno. Definitivamente a capacidade futura envolve rejeitar tradições e avançar ao que progride e empodera a todos.

Se viver em comunidade desde sempre foi um acolhimento fértil para a busca da felicidade, até o século XIX não se lia na história escrita dos filósofos, antropólogos, psicanalistas e estudiosos onde a mulher estava nesse processo de alegria de vida em comum. Mas ela estava e esteve em todos os lugares em todos os espaços e, em muito, foi responsável pela criação das gerações. A emergência de novas famílias já está sendo recebida e ela foi revigorada inclusive juridicamente - e assim deve ser o papel da mulher, que necessita de uma posição emergente numa sociedade que se faça nova.

A mulher foi deus na pré-história, foi caçadora nas colônias antigas, foi mito, foi cientista e cerne da família desde que a humanidade existe. Porém a ela só atribuiu o papel de reprodutora e de doméstica sempre que a bibliografia social era escrita. Quando rumou à luta da busca por igualdade já era século XIX e XX e muito em matéria de valores já estava sedimentado.

Ao longo dos séculos XX e neste século, uma verdadeira virada de Copérnico ocorreu no mundo feminino. Lutas com movimentos organizados; participação política reconhecida constitucionalmente; normas sedimentando oportunidades que outrora eram masculinas somente; e, sobretudo, uma nova geração de mulheres que se veem agentes da história, protagonistas da vida social, mães que são chefes 
no trabalho e chefes no trabalho que são gestoras públicas. Os papéis apareceram, mesmo que tardiamente, e são muitas mulheres nos dias de hoje que fazem do conceito de família o laço de afeto com seu filho, apenas; milhares vivem abertamente a paixão pela companheira, o que no passado lhes levariam à morte.

Todavia, nem esforços normativos emblemáticos, nem mesmo mudanças ocorridas por meios jurídicos em situações apartadas de alijamentos, nada é capaz de superar a força maior que transformação que existe dentro da mulher. Se ela racionalizar demais, pode correr o risco de seguir replicando os velhos hábitos machistas e, nesse caso, a luta pela sua emancipação deverá ter sido em vão. O propósito de pensar numa nova mulher, ambientada numa cultura transformadora, também começa por ela. O novo passa pela educação, pela informação, pela necessidade de se internalizar uma comunidade que seja unida por valores humanos de tal maneira que rusgas patrimonialistas tão ultrapassadas e que ressurja nos hábitos de mulheres contemporâneas. A nova mulher também precisa ela mesma ter uma nova mentalidade, ampliando e praticando um atuar vigoroso de seu papel, sem replicar velhos hábitos machistas.

Todo o esforço político-social e jurídico ainda não foi suficiente para erradicar os números alarmantes de violência doméstica, de sexismos, de feminicídios que assombram os dados brasileiros e mundiais. Mas por quê? Porque ainda se vê a discrepância de um país cuja presidenta é mulher, cuja ministra é mulher e os jornais apontam dados de mortes de mulheres por tortura em taxas assustadoras. Talvez a resposta esteja no poder que sustenta o íntimo dos valores, que desde as comunidades tradicionais até as atuais comunidades-sociedades são perpetuados em relação às discriminações e aos espaços reservados ao perfil segmentado da mulher na vida em comunidade.

Não basta dar a oportunidade por meio de políticas públicas. O que de fato mudaria o cenário é algo mais profundo e doloroso, que precisa urgentemente ser trabalhado em comunidade, que são os valores; as noções de poder que se ensinam aos filhos; a cultura secular que está nas entranhas e que desemboca em um sistema de sujeições, de dominação e de poder e que replica naturalmente em desigualdades que hoje se pode dizer: são construídas socialmente. 
A visão patriarcal enrustida por todas as classes sociais não enxerga que a nova mulher existe e a nova comunidade também, porém, distorcida pela visão dualista que separa papéis e sustenta desigualdades.

A luta deve continuar.

\section{REFERÊNCIAS}

ALVES, José Eustáquio Diniz; CAVENAGHI Suzana Marta. Dossiê - análises quantitativas e indicadores sociais: indicadores de desigualdade de gênero no brasil. mediações, Londrina, V. 17 N. 2, p. 83-105, JUL./DEZ. 2012.

ARISTÓTELES. Política. São Paulo: Martin Claret, 2002.

CORRÊA, Lindinalva Rodrigues. Direitos humanos das mulheres: doutrina, prática e direito comparado. 2. reimp. Curitiba: Juruá, 2012.

BAQUERO, Marcello. Construindo uma outra sociedade: o capital social na estruturação de uma cultura política participativa no Brasil. Revista de Sociologia e Política, Curitiba, n. 21, p. 83-108, nov. 2003. Disponível em:<http://www.scielo.br >. Acesso em: 09 de novembro de 2014.

BARROSO, Rafael Chaves Vasconcelos; FARIAS, Francisco Ramos de. GÊNERO E MEMÓRIA: uma construção dionisíaca. Caderno Espaço Feminino - Uberlândia -MG - v. 27, n. 1 - Jan/ Jun. 2014 - ISSN online 1981-3082.

BAUMAN, Zygmunt. Comunidade: a busca por segurança no mundo atual. Trad. Plínio Dentzien. Rio de Janeiro: Jorge Zahar, 2003.

BORELLI, Andrea. Meu nome é Maria da Penha: Considerações sobre a Lei de violência doméstica e familiar contra a mulher no Brasil. Caderno Espaço Feminino - Uberlândia-MG - v. 26, n. 2 - Jul/Dez. 2013 - ISSN on-line 1981-3082.

BOTTOMORE, T. Dicionário do pensamento social do século XX. Rio de Janeiro: Zahar, 1996.

BRASIL. Presidência da República. Secretaria de Políticas para as Mulheres. Relatório Anual Socioeconômico da Mulher. $1^{\text {a }}$ Impressão. Brasília: Secretaria de Políticas para as Mulheres, Novembro, 2013. 170 pg. 
BUBER, Martin. O socialismo utópico. 2. ed. São Paulo: Perspectiva, 2007.

COSTA, Marli Marlene Moraes da. A transversalidade das políticas públicas na perspectiva de gênero. In: COSTA, Marli M. M. da; LEAL, Mônia Clarissa Henning. Direitos sociais e políticas públicas: desafios contemporâneos. Tomo 13, Santa Cruz do Sul: EDUNISC, 2013.

COSTA, Marli Marlene Moraes da; D'OLIVEIRA, Mariane Camargo. Idiossincrasias femininas [recurso eletrônico] - Curitiba: Multideia, 2013.

ETZIONI, Amitai. La nueva regla del oro: comunidad y moralidad em uma sociedad democrática. Barcelona: Paidós, 1999.

ETZIONI, Amitai. La tercera via hacia una buena sociedad: propuestas desde El comunitarismo. Sagasta: Trotta,S. A, 2000.

GARCIA, Leila Posenato et al. Violência contra a mulher: feminicídios no Brasil. Instituto de Pesquisa Econômica Aplicada - Ipea. Texto digital. In. www.ipea.gov.br. Acesso em 09 de novembro de 2014.

GOHN, Maria da Glória. O protagonismo da sociedade civil: movimentos sociais, ONGs e redes solidárias. 2. ed. São Paulo: Cortez, 2008.

INSTITUTO BRASILEIRO DE GEOGRAFIA E ESTATÍSTICA - IBGE. Pesquisa Nacional por Amostra de Domicílios. 2009. Disponível em: http://www.ibge.gov.br/home/estatistica/populacao/ trabalhoerendimento/pnad2009/. Acesso em: 01 de novembro de 2014.

INGLEHART, Ronald; WELZEL, Christian. Modernização, mudança cultural e democracia: a sequência do desenvolvimento humano. Trad. Hilda Maria Lemos Pantoja. São Paulo: Francis, 2009.

IPEA. Instituto de Pesquisa Econômica Aplicada. Retrato das Desigualdades. 2. ed. Luana Pinheiro et al. Programa Igualdade de Gênero e Raça UNIFEM. Diretoria de Estudos Sociais. In: Programa Igualdade de Gênero e Raça unifemgeneroraca@undp.org.br.

IPEA. Instituto de Pesquisa Econômica Aplicada. Retrato das Desigualdades de gênero e raça. In: Programa Igualdade de Gênero e Raça: unifemgeneroraca@undp.org.br.

KYMLICKA, Will. Filosofia política contemporânea. Trad. Luiz Carlos Borges. São Paulo: Martins Fontes, 2006.

LEMOS, Carolina Teles. A (re)construção do conceito de comunidade como um desafio à sociologia da religião. Revista Estudos de Religião, v. 23, n. 36, 201-216, jan./jun. 2009. 
MILES, Rosalind. A história do mundo pelas mulheres. Trad. Bárbara Heliodora. Rio de Janeiro: LTC, 1989.

NEGREIROS, Teresa Creusa de Góes Monteiro. Masculino e feminino na família contemporânea.

Revista Estudos e Pesquisas em Psicologia, UERJ, RJ, ano 4 n. 1, $1^{\circ}$ semestre 2004.

OLIVEIRA, Luciano. Comunidade e sociedade - notas sobre a atualidade do pensamento de Ferdinand Tõnnies. Cad. Estudos Soc., Recife, v.4 n.J,p.IOS-118,jan./jun., 1988.

PATEMAN, Carole. O contrato sexual. Rio de Janeiro: Paz e Terra. 1993.

PORTO, Rosane Teresinha Carvalho; COSTA, Marli Marlene Moraes da. Justiça Restaurativa \& Gênero: por uma humanização que desarticule a violência [recurso eletrônico]. Curitiba: Multideia, 2014.

REIS, Suzéte Silva; COSTA, Marli Marlene Moraes da. Trabalho, educação \& gênero: desafios e perspectivas da inserção da mulher no mercado de trabalho no século XXI [recurso eletrônico]. Curitiba: Multideia, 2014.

RIBEIRO, Ednaldo Aparecido. Cultura Política e Gênero no Brasil: Estudo exploratório sobre as bases da sub-representação feminina. IV Congresso Latino Americano de Opinião Pública da WAPOR, Belo Horizonte - BrasilAT 08 Opinião Pública, Cultura Política e Democracia, 2014. In: www.revista.ufpe.br/politicahoje/ index.php/politica/article/.../220 de EA Ribeiro - 2014.

SAFFIOTI, Heleieth. Gênero, patriarcado e violência. São Paulo: Fundação Perseu Abramo, 2004.

SCHMIDT, João Pedro. Comunidade e comunitarismo: considerações sobre a inovação da ordem sociopolítica. Ciências Sociais Unisinos, São Leopoldo, Vol. 47, N. 3, p. 300-313, set/dez 2011.

SCHMIDT, João Pedro. Amitai Etzioni e o paradigma comunitarista: da sociologia das organizações ao comunitarismo responsivo. Texto inédito.

SEN, Amartya. Desenvolvimento como liberdade. Tradução Laura Teixeira Motta. São Paulo: Companhia das Letras, 2000.

SENNETT, Richard. A cultura do novo capitalismo. Tradução Clóvis Marques. Rio de Janeiro: Record, 2006.

SILVEIRA, Clara Maria Holanda. A mulher é Eva, o homem é Adão? Reflexões sobre o significado de ser homem e de ser mulher na sociedade. Caderno Espaço Feminino - Uberlândia-MG v. 27, n. 1 - Jan/Jun. 2014 - ISSN on-line 1981-3082. 
STEARNS, Peter N. História das relações de gênero. Tradução Mirna Pinsky. 2. ed. São Paulo:Contexto, 2013.

TOURAINE, Alain. O Mundo das mulheres. Petrópolis: Vozes, 2011.

VALOBRA, Adriana María. Los caminos de la historia de las mujeres y de género. In: Fronteiras de gênero. Organizadoras Joana Maria Pedro, Silvia Maria Fávero Arend, Carmem Sílvia de Moraes Rial. Florianópolis: Ed. Mulheres, 2011.

Recebido em: abr/2015

Aprovado em: jun/2015 